\title{
Ras mediates translation initiation factor 4E-induced malignant transformation
}

\author{
Anthoula Lazaris-Karatzas, ${ }^{1}$ Mark R. Smith, ${ }^{2}$ Robert M. Frederickson, ${ }^{1}$ Maria L. Jaramillo, ${ }^{1}$ \\ Ya-lun Liu, ${ }^{2}$ Hsiang-fu Kung, ${ }^{3}$ and Nahum Sonenberg ${ }^{1,4}$ \\ ${ }^{1}$ Department of Biochemistry and McGill Cancer Center, McGill University, Montréal, Québec, Canada H3G 1Y6; \\ ${ }^{2}$ Biological Carcinogenesis and Development Program, Program Resources, Inc./DynCorp, Biological Response Modifiers \\ Program, Division of Cancer Treatment, National Cancer Institute, Frederick Cancer Research and Development Center, \\ Frederick, Maryland 21702 USA; ${ }^{3}$ Laboratory of Biochemical Physiology, Biological Response Modifiers Program, Division of \\ Cancer Treatment, National Cancer Institute, Frederick Cancer Research and Development Center, \\ Frederick, Maryland 21702-1201 USA
}

Translation initiation factor eIF-4E binds to the eukaryotic mRNA $5^{\prime}$ cap structure $\left(\mathrm{m}^{7} \mathrm{Gppp} N\right.$, where $N$ is any nucleotide). eIF-4E is a limiting factor in translation and plays a key role in regulation of translation. We have shown previously that overexpression of eIF-4E in rodent fibroblasts results in tumorigenic transformation. eIF-4E also exhibits mitogenic activity when microinjected into serum-starved NIH-3T3 cells. To understand the mechanisms by which eIF-4E exerts its mitogenic property, we examined the involvement of the Ras signaling pathway in this activity. Here, we report that Ras is activated in eIF-4E-overexpressing cells, as the proportion of GTP-bound Ras is increased. Overexpression of the negative effector of cellular Ras, GTPase activating protein, causes reversion of the transformed phenotype. Furthermore, we show that neutralizing antibodies to Ras, or a dominant-negative mutant of Ras, inhibit the mitogenic activity of eIF-4E. We conclude that eIF-4E exerts its mitogenic and oncogenic activities by the activation of Ras.

[Key Words: eIF-4E; translation; signal transduction; revertants]

Received May 27, 1992; revised version accepted July 17, 1992

Control of polypeptide chain synthesis plays an important role in cell proliferation (for a recent review, see Hershey 1991). Translation rates always reflect the growth state of eukaryotic cells in culture. Regulation of translation occurs primarily at the initiation step, in response to disparate conditions, including viral infection, heat shock, growth factors, and hormones (Bonneau and Sonenberg 1987; Morley and Traugh 1990; Huang and Schneider 1991). An important target for control of translation is the process of ribosome binding to mRNA. Several cis-acting elements on the mRNA and trans-acting protein factors are involved in this process. The cis-acting elements on the mRNA include (1) the 5' cap structure, $\mathrm{m}^{7} \mathrm{Gppp} N$ (where $N$ is any nucleotide), which facilitates ribosome binding (Rhoads 1988; Sonenberg 1988); (2) secondary structure, which negatively regulate ribosome binding (Pelletier and Sonenberg 1985; Manzella and Blackshear 1990); and (3) the consensus sequence flanking the initiator AUG (Kozak 1986). The trans-acting factors that function in mRNA binding to ribosomes include at least three initiation factors: eIF-4A, eIF-4B, and eIF-4F. eIF- $4 \mathrm{~F}$ itself is composed of three polypep-

${ }^{4}$ Corresponding author. tides: (1) a 24-kD phosphoprotein termed eIF-4E, which contains a cap-binding site and binds specifically to the mRNA cap structure; (2) a 50-kD polypeptide, which exists as two highly homologous eIF-4A gene products (Nielsen and Trachsel 1988), [both eIF-4A polypeptides exhibit ATPase and RNA helicase activities (A. Pause, unpubl.)|; and (3) a 220-kD polypeptide termed p220, whose function is unknown, but whose integrity is required for the function of eIF-4F (Sonenberg 1987). There is considerable evidence to support the hypothesis that eIF-4A, in combination with eIF-4B, unwinds the mRNA 5 ' secondary structure, following the initial binding of eIF-4F to the mRNA cap structure (Ray et al. 1985; Rozen et al. 1990; Jaramillo et al. 1991).

The smallest subunit of the complex, eIF-4E, plays an important role in regulation of cell proliferation, as demonstrated by two different assay systems: (1) Overexpression of eIF-4E in NIH-3T3 cells results in their tumorigenic transformation (Lazaris-Karatzas et al. 1990), and when overexpressed in HeLa cells eIF-4E causes aberrant growth (deBenedetti and Rhoads 1990); and (2) eIF-4E induces DNA synthesis when microinjected into quiescent NIH-3T3 cells (Smith et al. 1990). These results are consistent with the finding that eIF-4E is present in lim- 
iting amounts in the cell relative to other initiation factors (Hiremath et al. 1985; Duncan et al. 1987). Moreover, the biochemical (Joshi-Barve et al. 1990) and biological (Morley et al. 1991) activities of eIF-4E depend on its state of phosphorylation on Ser-53 (Rychlik et al. 1987). Phosphorylation of eIF-4E is increased in response to mitogens, growth factors, and the transforming src and ras genes, suggesting that eIF-4E is an important component of various mitogenic signaling pathways (Marino et al. 1989; Morley and Traugh 1989; Kaspar et al. 1990; Frederickson et al. 1991, 1992; Rinker-Schaeffer et al. 1992).

Ras proteins play a critical role in transduction of mitogenic signals in mammalian cells. Ras exists in an active GTP-bound state and in an inactive GDP-bound state (Barbacid 1987; Bourne et al. 1990). We demonstrated previously that transformation of primary cells by eIF-4E requires the cooperation of an immortalizing gene such as myc or E1A (Lazaris-Karatzas and Sonenberg 1992). Furthermore, expression of transforming tyrosine kinases, which function through a Ras pathway (Smith et al. 1986), in NIH-3T3 cells or expression of an activated Ras mutant in rat embryo fibroblast (REF) cells leads to a significant increase in eIF-4E phosphorylation (Frederickson et al. 1991; Rinker-Schaeffer et al. 1992). In addition, we reported that eIF-4E phosphorylation in $\mathrm{PCl} 2$ cells, in response to nerve growth factor (NGF), is abrogated in cells expressing a dominant-negative mutant of c-Ras (Ha-c-Ras Asn-17; Frederickson et al. 1992). Taken together, these data raise the possibility that the Ras signaling pathway mediates cellular transformation by eIF-4E. In this report we test this hypothesis and show a direct link between eIF-4E expression and Ras function by demonstrating that eIF-4E overexpression leads to an increase in GTP-Ras complex and thus to Ras activation. In addition, overexpression of GAP (GTPase activating protein) reverts the eIF-4E-induced transformed phenotype. Furthermore, we show that neutralizing antiRas antibodies or a dominant-negative mutant of Ras (Ha-c-Ras Asn-17) block the mitogenic activity of eIF-4E.

\section{Results}

eIF-4E overexpression activates Ras

One possible mechanism of eIF-4E transformation is through activation of the Ras signaling transduction pathway. To address this possibility directly, we examined the effect of eIF-4E overexpression on Ras activity by measuring the percentage of GTP-bound Ras relative to total Ras-bound nucleotides. Ras is biologically active when bound to GTP and inactive when bound to GDP (Barbacid 1987; Bourne et al. 1990). The GTP/GDP + GTP ratio was determined following metabolic labeling with $\left[{ }^{32} \mathrm{P}\right]$ orthophosphate, immunoprecipitation of Ras, and analysis of GTP and GDP by thin layer chromatography (TLC). The amount of GTP-bound Ras as a proportion of total Ras-bound nucleotides is elevated threefold in NIH-3T3/eIF-4E-overexpressing cells relative to the parental cells $(20 \%$ as compared with $7 \%$ GTP; Fig. 1A, cf. lanes 1 and 2 with lanes 3 and 4; Table 1) There was no difference in the level of Ras protein between parental NIH-3T3 and eIF-4E-overexpressing cells, as determined by immunoblot analysis with anti-Ras antibody (Fig. 1B, cf. lane 1 with 2). These results demonstrate that overexpression of eIF-4E effects Ras activation.

\section{GAP overexpression reverts the eIF-4E-transformed phenotype}

To further substantiate the conclusion that Ras is directly involved in eIF-4E function and cellular transformation, we wished to determine the effect of overexpression of GAP on eIF-4E-induced cell transformation. GAP increases the rate at which Ras is converted from the active GTP-bound to the inactive GDP-bound state (Trahey and McCormick 1987). GAP is therefore a negative regulator of Ras. We reasoned that if transformation by eIF-4E is mediated by Ras, then down-regulation of Ras activity by overexpression of GAP should revert eIF-4Einduced transformation. In the experiments shown here, we used REFs that had been transformed by eIF-4E and selected for G418 resistance (Lazaris-Karatzas and Sonenberg 1992). These cells were chosen over eIF-4Etransformed NIH-3T3 cells, because they exhibit a more conspicuous transformed morphology than NIH-3T3, a feature that facilitated the screening for revertants. eIF-

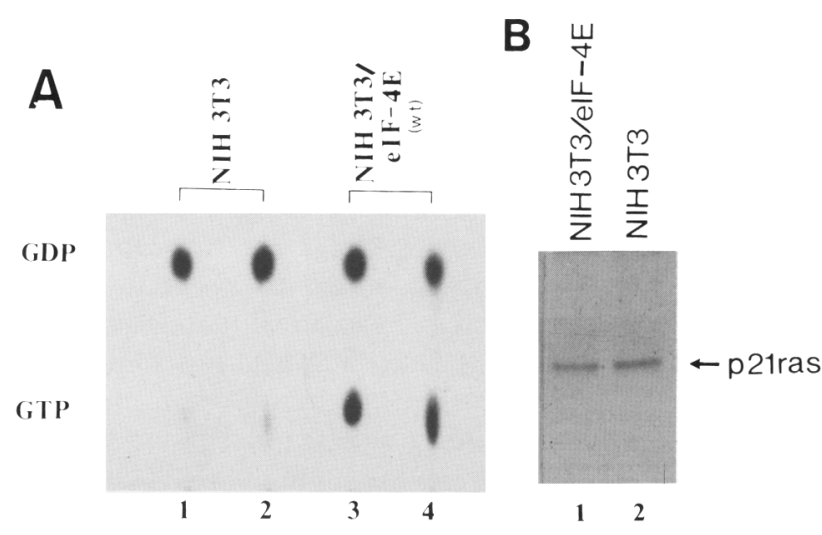

Figure 1. Increased p21/GTP, but not p21/Ras protein amounts, in eIF-4E-overexpressing cells. $(A)$ Serum-starved cells were labeled for $10 \mathrm{hr}$ with $\left[{ }^{32} \mathrm{P}\right]$ orthophosphate and lysed, and p21/Ras was immunoprecipitated with monoclonal antibody Y13-259. Ras-bound ${ }^{32}$ p-labeled guanine nucleotides were eluted and separated by TLC, as described in Materials and methods. Reactions were performed in duplicate and contained the following cell lines: (Lanes 1,2) NIH-3T3; (lanes 3,4) transformed NIH-3T3/eIF-4E (wt). TLC plates were exposed for 2 days. Migration of GDP and GTP standards are indicated at left. (B) Ras immunoprecipitates $(100 \mu \mathrm{g})$ were electrophoresed on a $12.5 \%$ polyacrylamide gel and processed for Western blot analysis as described in Materials and methods. Ras was detected by the ECL detection kit. The autoradiograph represents a 20 -sec exposure. (Lane 1) Transformed NIH-3T3/elF-4E (wt); (lane 2) NIH-3T3 cells. 
Table 1. Proportion of GTP-bound Ras in transformed and nontransformed cell lines

\begin{tabular}{|c|c|c|c|}
\hline Cell line & $\begin{array}{l}\text { GTP-bound Ras } \\
(\%)\end{array}$ & Avg. & $\begin{array}{l}\text { Response } \\
\text { (fold } \\
\text { stimulation) }\end{array}$ \\
\hline \multicolumn{4}{|c|}{ Experiment 1} \\
\hline NIH-3T3 & $6.8,7.2,7.0$ & 7.0 & - \\
\hline NIH-3T3/eIF-4E & $20.0,21.0,20.0$ & 20.3 & 2.9 \\
\hline \multicolumn{4}{|c|}{ Experiment 2} \\
\hline $\begin{array}{l}\text { E1A } \\
\text { E1A/pMV7/ }\end{array}$ & $5.6,4.4,5.2,7.2$ & 5.6 & - \\
\hline eIF-4E & $15.2,16.0,17.6,14.8$ & 15.9 & 2.8 \\
\hline $\begin{array}{l}\text { pMV7/eIF-4E } \\
\text { MV7/eIF-4F }\end{array}$ & $14.4,14.0,15.2,15.2$ & 14.7 & 2.6 \\
\hline $\begin{array}{c}\text { pMV//eIF-4E } \\
+ \text { hGAP C1 } \\
\text { pMV7/eIF-4E }\end{array}$ & $5.0,5.2)$ & & \\
\hline $\begin{array}{l}+ \text { hGAP C2 } \\
\text { pMV7/eIF-4E }\end{array}$ & $5.2,5.2$ & 4.7 & 0.8 \\
\hline+ hGAP C3 & $3.2,4.4$ & & \\
\hline
\end{tabular}

${ }^{a}$ Values were calculated from the following formula: GTP

$\overline{1.5 \times \mathrm{GDP}+\mathrm{GTP}} \times 100$

4E-transformed REFs were cotransfected with an expression vector containing the human GAP cDNA under the control of the cytomegalovirus (CMV) promoter and a vector containing the hygromycin resistance gene. To obtain control eIF-4E-transformed REFs, we cotransfected the expression vector, lacking the human GAP cDNA, together with the vector containing the hygromycin resistance gene, and used pooled hygromycin-resistant cells for further experiments. Thirty hygromycinresistant clones, from the transfection experiments with hGAP, were isolated for detailed studies. The majority of the clones $(\sim 80 \%)$ exhibited flat morphology, indicative of reversion of the transformed phenotype (Fig. 2). All of the 30 hygromycin-resistant clones were further examined for another transformation-specific propertygrowth in soft agar. A comparison of the morphology and growth in soft agar of revertant cell lines with those of the parental transformed cells is shown in Figure 2. The control, hygromycin-resistant-transformed cells, pMV7/ eIF-4E, exhibit a refractile and spindle-shaped morphology, as compared with the flat morphology of ElA-immortalized REFs (Fig. 2, cf. A with B). The revertant cells (clones $\mathrm{Cl}-\mathrm{C} 3$ ) are flat, translucent, grow in ordered arrays, and do not grow in soft agar (Fig. 2C-E). All of the clones that exhibited flat morphology (24 of 30) were incapable of growing in soft agar. The rest of the clones $(20 \%)$ exhibited a transformed morphology and grew in soft agar. One such transformed clone $(\mathrm{C} 4)$ is shown in Figure $2 \mathrm{~F}$. The three revertant clones $(\mathrm{Cl}-\mathrm{C} 3)$ were injected into athymic nude mice to examine their tumorigenic potential. Cells from the three clones failed to form tumors in nude mice, whereas the control eIF-4Etransformed cells formed tumors after a short latency period of 10-15 days (Table 2). We have repeated these experiments with eIF-4E-transformed NIH-3T3 cells, and have observed reversion of the transformed phenotype upon GAP overexpression (data not shown).

\section{Revertants arise owing to GAP overexpression}

Revertants could have arisen because of the overexpression of GAP or the loss of eIF-4E overexpression. To distinguish between these two possibilities, we performed Northern blot and immunoprecipitation analyses of eIF$4 \mathrm{E}$ RNA and protein. Northern blot analysis revealed that control eIF-4E-transformed REFs and revertant clones overexpressed eIF-4E mRNA to the same extent 150- to 100-fold as compared with ElA-immortalized REFs; Fig. 3A, cf. lanes $1-4$ with lane 5; Fig. 3B is a longer exposure of lanes 4 and 5). Two transcripts of 1.8 and 5.0 $\mathrm{kb}$ are detected. The shorter transcript arises from the use of the polyadenylation signal in the eIF-4E cDNA. Readthrough of this signal and termination in the $3^{\prime}$ long terminal repeat (LTR) of the vector yields a $5.0-\mathrm{kb}$ transcript (Lazaris-Karatzas et al. 1990). eIF-4E protein levels were analyzed by immunoprecipitation of ${ }^{35} \mathrm{~S}$-labeled cell extracts. Control eIF-4E-transformed REFs and revertant clones had 5-10 times more eIF-4E protein relative to the ElA-immortalized REFs (Fig. 3C, cf. lane 1 with lanes $2-6 \mid$. These results demonstrate that reversion of the transformed phenotype does not result from a reduction in eIF-4E protein.

We then assayed for overexpression of hGAP. Western blot analysis was performed for three of the revertant clones $(\mathrm{C} 1-\mathrm{C} 3)$ by use of a polyclonal human GAP antibody capable of recognizing both the human and murine GAP proteins. The steady-state amount of GAP protein in these clones is six to eight times higher than in control E1A-immortalized REF cells (Fig. 4, cf. lanes 3-5 with lane 1) and approximately three times higher than in control eIF-4E-transformed REF cells (Fig. 4, cf. lanes 3-5 with lane 2). Hygromycin-resistant clones that still displayed the transformed phenotype were also examined for GAP expression. The amount of GAP in these cells is similar to that in the transformed control cells (data not shown). Thus, there is an excellent correlation between the extent of GAP overexpression and the reversion of the transformed phenotype. It is noteworthy, however, that the level of endogenous GAP is elevated (about threefold) in eIF-4E-transformed cells relative to ElA-immortalized cells (cf. lane 1 with 2). This phenomenon has precedence, as it has been shown that transformation of NIH-3T3 cells by src or lck results in an increase in the steady-state level of GAP (Ellis et al. 1990; DeClue et al. 1991a; Veillette et al. 1992).

Ras activity, as determined by the percentage of GTPbound Ras, was also examined. Ras in control ElA-immortalized REFs is almost entirely GDP bound $15.6 \%$ GTP; Fig. 5, lanes 1,2; Table 1). In ElA-immortalized REFs overexpressing eIF-4E and in control REF cells overexpressing eIF-4E, the proportion of GTP-bound Ras relative to total Ras rises threefold $115 \%$ GTP; Fig. 5, cf. lanes 1 and 2 with lanes 3-6; summarized in Table 1). As expected, GAP overexpression in eIF-4E-transformed cells results in a decrease of GTP-bound Ras to levels 
Figure 2. Morphology and growth in soft agar of eIF-4E-transformed and revertant cell lines. The procedure for growth in soft agar was as described in Materials and methods. (A) ElA-immortalized REFs; $(B)$ control $\mathrm{pMV7/eIF-4E-transformed} \mathrm{REFs;}(C-E)$ pMV7/eIF-4E + hGAP /three different revertant clones); (D) a pMV7/eIF-4E + hGAPtransformed clone. Magnification, 160x.
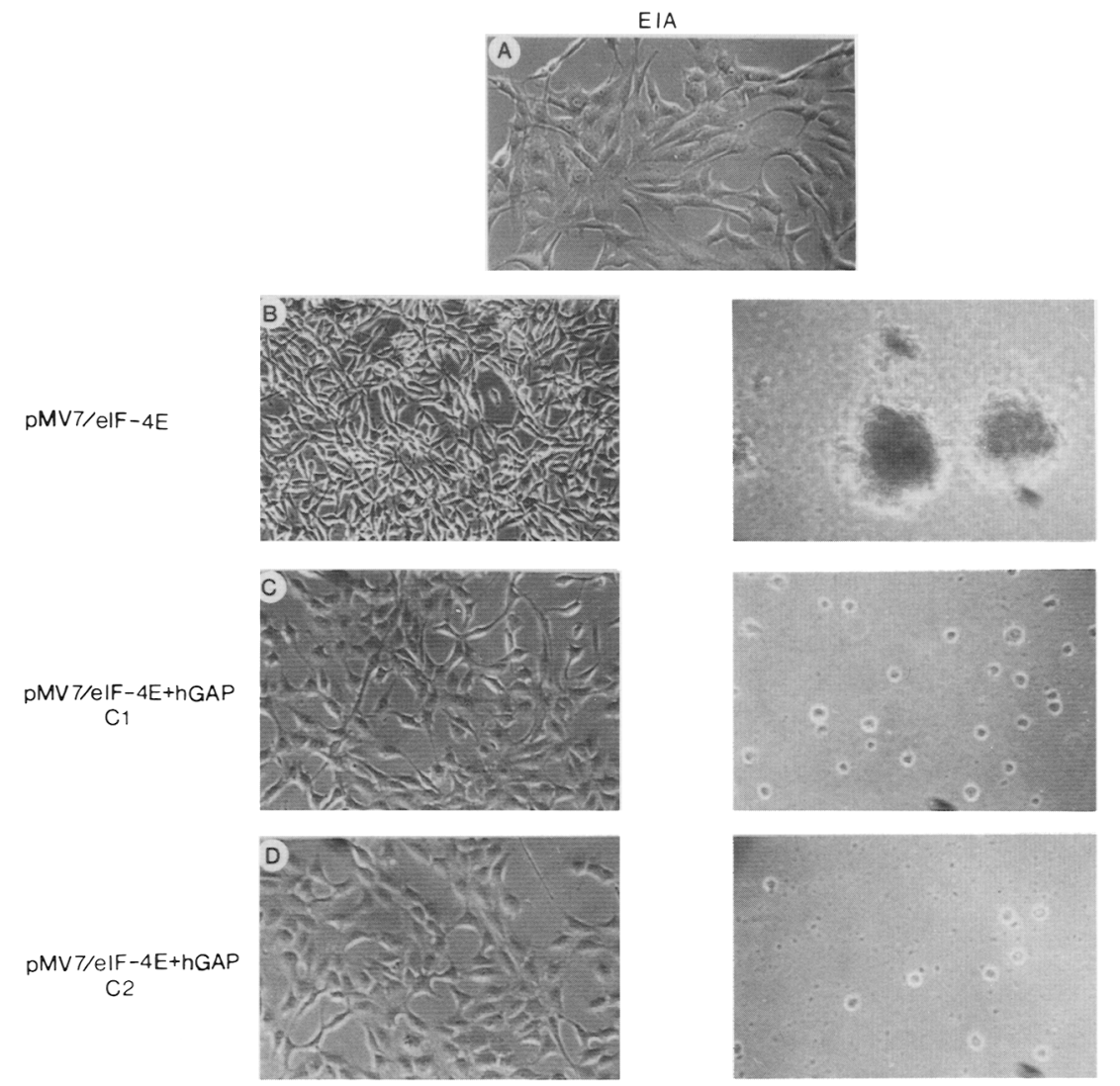

pMN7/eIF-4E+hGAP

C3
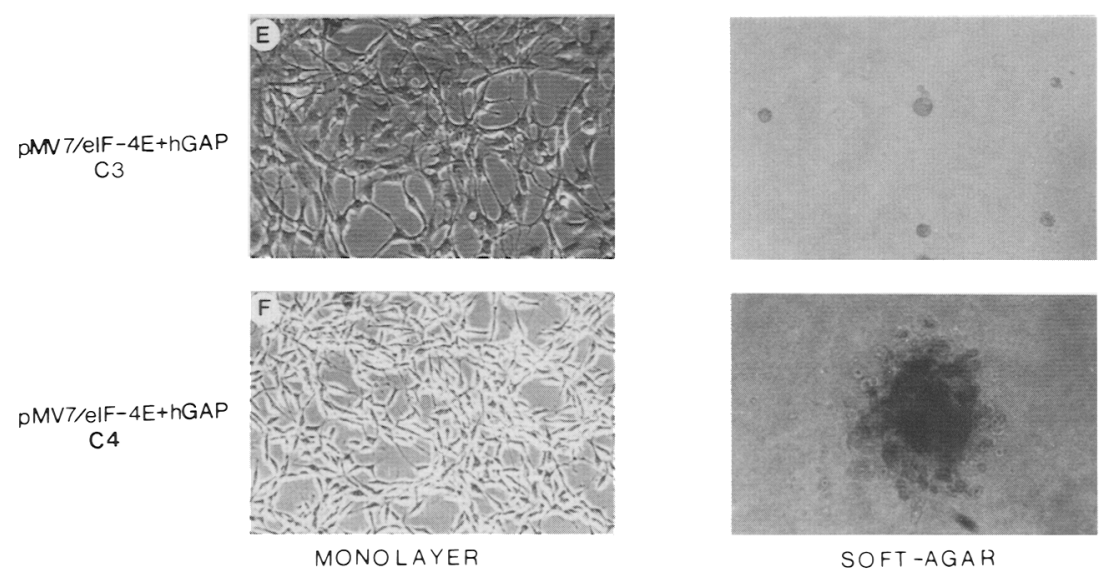

SOFT-AGAR similar to those detected in E1A-immortalized REFs (Fig. 5, cf. lanes 7-9 with lanes 1 and 2; Table 1). Taken together, our results strongly suggest that eIF-4E transforms cells by a Ras-dependent pathway.

Table 2. Tumorigenicity in nude mice

\begin{tabular}{lcc}
\hline Cells & $\begin{array}{l}\text { Number of tumors/mice } \\
\text { injected }\end{array}$ & $\begin{array}{c}\text { Latency } \\
\text { (days) }\end{array}$ \\
\hline E1A & $0 / 2$ & - \\
pMV7/eIF-4E & $3 / 3$ & $10-15^{3}$ \\
pMV7/eIF-4E + hGAP & $0 / 6$ & - \\
\hline
\end{tabular}

Tumors displayed unlimited growth.
eIF-4E phosphorylation levels in eIF-4E-transformed REFs and revertant cells are comparable

elF-4E activity correlates positively with its state of phosphorylation. It is possible that the revertant cells contain hypophosphorylated eIF-4E. This would explain their nontransformed phenotype, as eIF-4E(ala)-overexpressing cell lines are not transformed (Lazaris-Karatzas et al. 1990|. To test this possibility, revertant cells were metabolically labeled with ${ }^{32} \mathrm{P}$ and immunoprecipitated with eIF-4E antibody. Control eIF-4E-transformed REFs contain increased amounts of phosphorylated eIF-4E, relative to ElA-immortalized REFs (Fig. 6, cf. lanes 1 and 2 with lanes 3 and 4). Revertant cell lines displayed a sim- 

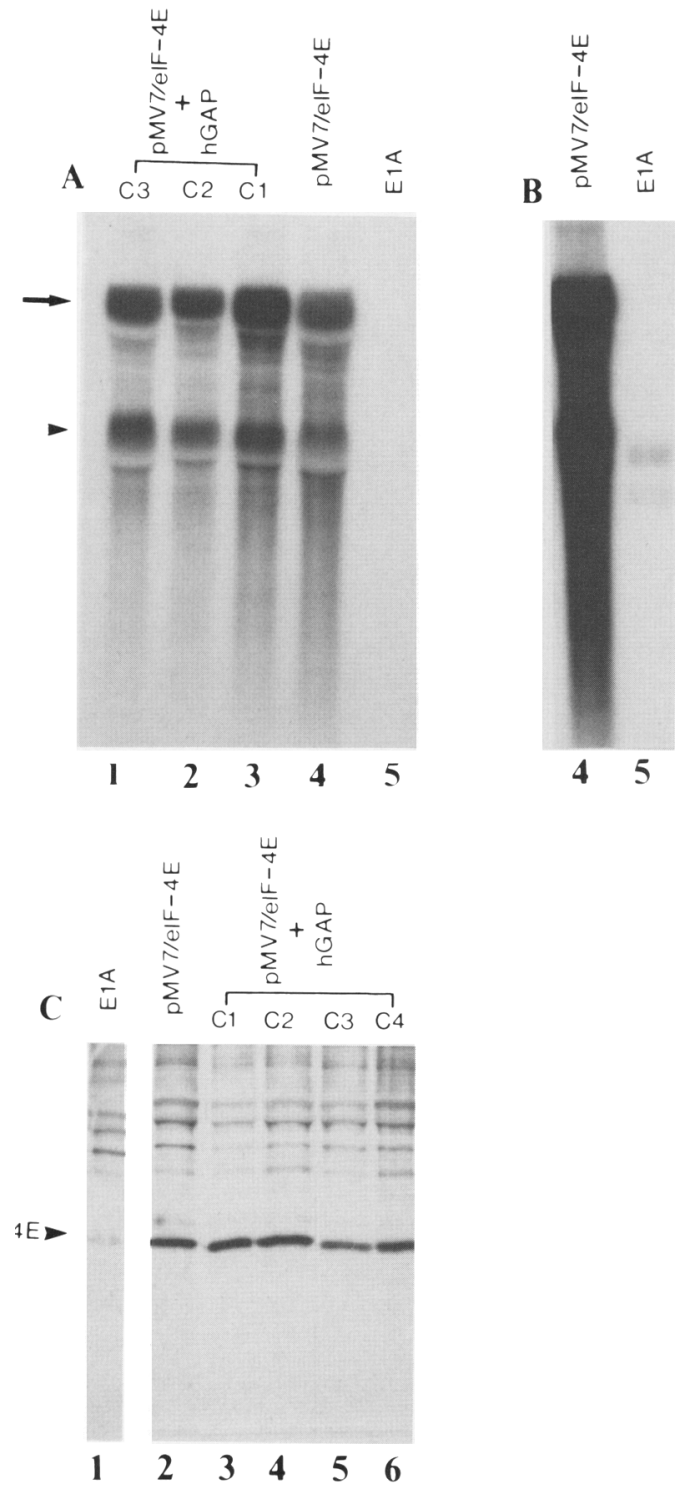

Figure 3. Northern and immunoprecipitation analysis of eIF$4 \mathrm{E}$ in E1A-immortalized, eIF-4E-transformed, and hGAP revertant REFs. $(A)$ Poly $(A)^{+}$mRNA was separated on a $1.25 \%$ formaldehyde agarose gel, blotted onto a nylon membrane, and hybridized to a eIF-4E cDNA probe as described in Materials and methods. The blot was exposed for $2 \mathrm{hr}$ at $-70^{\circ} \mathrm{C}$ on Kodak X-Omat XAR-5 film. The arrow indicates the 5 -kb transcript; the arrowhead indicates the $1.6-\mathrm{kb}$ transcript. (Lanes 1-3) pMV7/eIF-4E + hGAP, revertant clones C1-C3; (lane 4) control pMV7/eIF-4E-transformed REFs; (lane 5) E1A-immortalized REFs. (B) Overexposure of lanes 4 and 5 from $A$. The blot was exposed for $24 \mathrm{hr}$. $|C|$ eIF-4E was immunoprecipated from $\left[{ }^{32} \mathrm{~S}\right]$ methionine-labeled cell extracts as described in Materials and methods with polyclonal rabbit antibody against a mouse eIF-4E synthetic peptide (Lazaris-Karatzas et al. 1990). Exposure was for $24 \mathrm{hr}$. The description of the lanes is as in $A$.

ilar increase in the amount of phosphorylated eIF-4E (Fig. 6 , cf. lanes 1 and 2 with lanes 5-8). These results were further confirmed by two-dimensional gel electrophoresis (data not shown). Consequently, we conclude that the
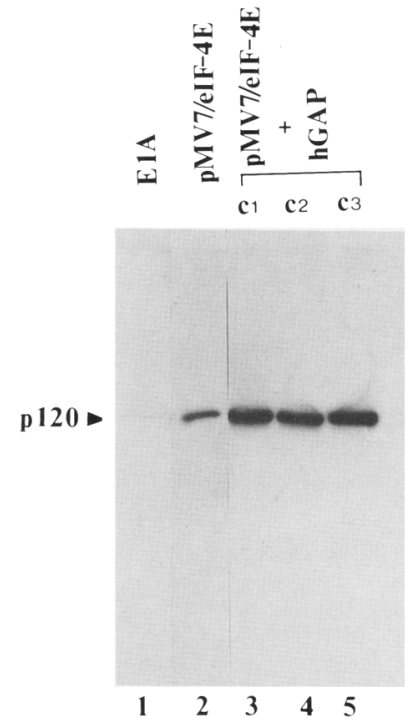

Figure 4. Immunoblot analysis of hGAP in control, transformed, and revertant cell lines. Total cell extracts $(75 \mu \mathrm{g})$ were electrophoresed on an $8 \%$ polyacrylamide gel, transferred to nylon, and blotted with anti-GAP antibody, as described in Materials and methods. The autoradiograph represents a 24-hr exposure. (Lane 1) ElA-immortalized REFs; (lane 2) control pMV7/eIF-4E-transformed REFs; (lanes 3-5) pMV7/elF$4 \mathrm{E}+$ hGAP, revertant clones $\mathrm{Cl}-\mathrm{C} 3$.

reversion of the tr:nsformed phenotype is not the result of a decrease in the phosphorylation state of eIF-4E.

\section{Anti-Ras antibody inhibits the mitogenic activity of eIF- $4 E$}

To further support our conclusion that eIF-4E activity is mediated through Ras, we examined eIF-4E mitogenic

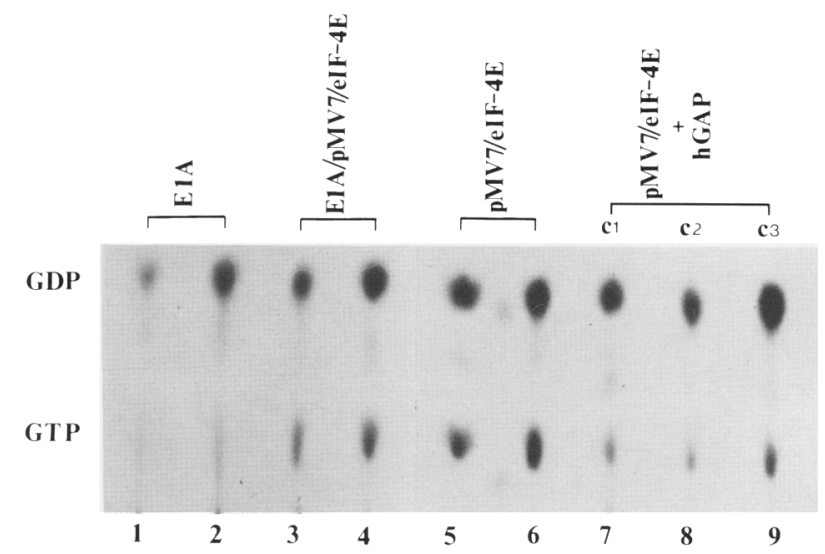

Figure 5. hGAP overexpression decreases the Ras/GTP complex. An autoradiograph is shown of TLC of the nucleotides eluted from Ras, performed as described in Fig. 1 and Materials and methods. TLC plates were exposed for 2 days. Experiments were performed in duplicate and contained the following cell lines: (Lanes 1,2) ElA-immortalized REFs; (lanes 3, 4) ElA-immortalized REFs transformed by eIF-4E, E1A/pMV7/eIF-4E; (lanes 5,6) control pMV7/eIF-4E-transformed REFs; (lanes 7-9) pMV7/eIF-4E + hGAP, revertant clones Cl-C3. 


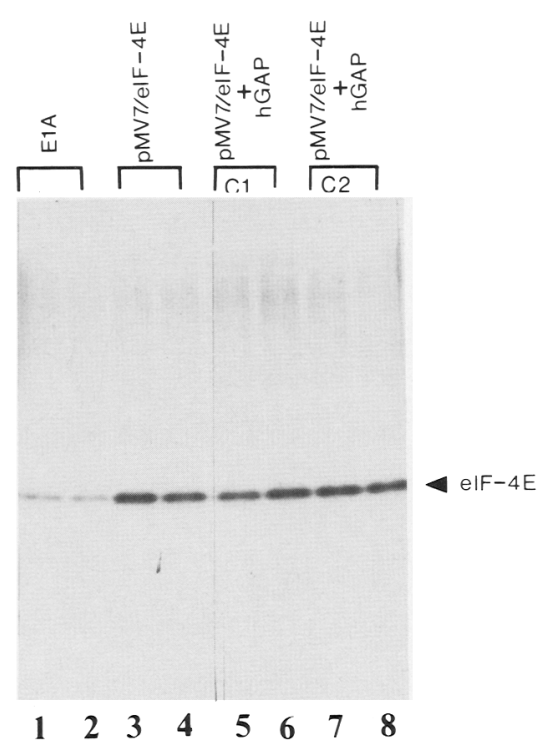

Figure 6. hGAP overexpression does not affect eIF-4E phosphorylation. Cells were labeled with $\left[{ }^{32} \mathrm{P}\right]$ orthophosphate and lysed, and eIF-4E was immunoprecipitated as described in Materials and methods. The blot was exposed for $24 \mathrm{hr}$. Experiments were performed in duplicate and contain the following cell lines: (Lanes 1,2) ElA-immortalized REFs; (lanes 3,4) control pMV7/eIF-4E-transformed REFs; (lanes 5-8) pMV7/eIF$4 \mathrm{E}+$ hGAP, revertant clones $\mathrm{C} 1$ and $\mathrm{C} 2$.

activity in serum-starved cells. Microinjection of eIF-4E into serum-starved NIH-3T3 cells induces DNA replication (Smith et al. 1990). To examine the involvement of Ras in this activity, we used an anti-Ras monoclonal antibody, Y13-259 (Furth et al. 1982) that blocks Ras activity when microinjected into cells (Mulcahy et al. 1985). This monoclonal antibody also neutralizes the mitogenic activity of coinjected purified Ras protein (Kung et al. 1986) and inhibits the proliferation of several tumor cell lines (Stacey et al. 1987). The Y13-259 antibody is not a general suppressor of mitogenic activity, inasmuch as it does not block the mitogenic activity and transformation induced by viral Raf or Mos (Smith et al. 1986). Microinjection of recombinant eIF-4E into quiescent NIH-3T3 cells induced DNA synthesis $(\sim 14$-fold; Fig. 7A; Table 3), whereas the mutant eIF-4E(ala) protein caused a much smaller induction (less than threefold) in DNA synthesis (Fig. 7B; Table 3), as did injection of BSA (Table 3). Coinjection of anti-Ras neutralizing antibody Y13-259 with eIF-4E effectively repressed the mitogenic activity of eIF-4E (Fig. 7C; Table 3). In contrast, a nonneutralizing Ras antibody, Y13-238 (Furth et al. 1982), had minimal inhibitory activity $(<10 \%)$ on eIF-4E mitogenic activity (Fig. 7D; Table 3). This experiment strongly argues that functional Ras is required for eIF-4E activity and that eIF-4E shares a common mitogenic signaling pathway with Ras.

\section{A dominant-negative mutant of Ras inhibits eIF-4E mitogenic activity}

In a different approach to show that eIF-4E mitogenic activity is dependent on Ras, we used a dominant-negative mutant of $\mathrm{Ha}-\mathrm{c}-\mathrm{Ras}$ in which Ser-17 was changed to asparagine (Feig and Cooper 1988). Expression of Ha-cRas Asn-17 inhibits the proliferation of NIH-3T3 cells presumably by competing with c-Ras, thereby blocking normal Ras protein function (Feig and Cooper 1988). Microinjection of recombinant wild-type $\mathrm{Ha}-\mathrm{c}$-Ras into serum-starved NIH-3T3 cells caused a significant induction ( $\sim 18$-fold) of DNA synthesis (Table 4 ), as reported previously (Stacey and Kung 1984). In contrast, microinjection of the Ha-c-Ras Asn-17 mutant, at the same con-
Figure 7. The mitogenic activity of eIF$4 \mathrm{E}$ is blocked by coinjection of the rasneutralizing antibody Y13-259. Approximately 75 cells within the area of the photomicrographs were microinjected with eIF-4E $(3 \mathrm{mg} / \mathrm{ml})(A)$; eIF-4E (Ala-53, $3 \mathrm{mg}$ / ml) $(B)$; eIF-4E $(3 \mathrm{mg} / \mathrm{ml}+\alpha 259(2 \mathrm{mg} /$ ml) $|C|$; and eIF-4E $\{3 \mathrm{mg} / \mathrm{ml}+\alpha 238 / 2$ $\mathrm{mg} / \mathrm{ml})(D)$. The injected cultures were maintained in $0.5 \%$ FCS for $18-20 \mathrm{hr}$, pulsed with $\left[{ }^{3} \mathrm{H}\right]$ thymidine $(0.5 \mu \mathrm{Ci} / \mathrm{ml})$ for $4 \mathrm{hr}$, and fixed with $3.5 \%$ gluteraldehyde; coverslips were mounted onto glass microscope slides, immersed in photographic emulsion (NTB2), and autoradiographed for $48 \mathrm{hr}$. The slides were stained with Giemsa, and the injected areas were photographed at $800 \times$.

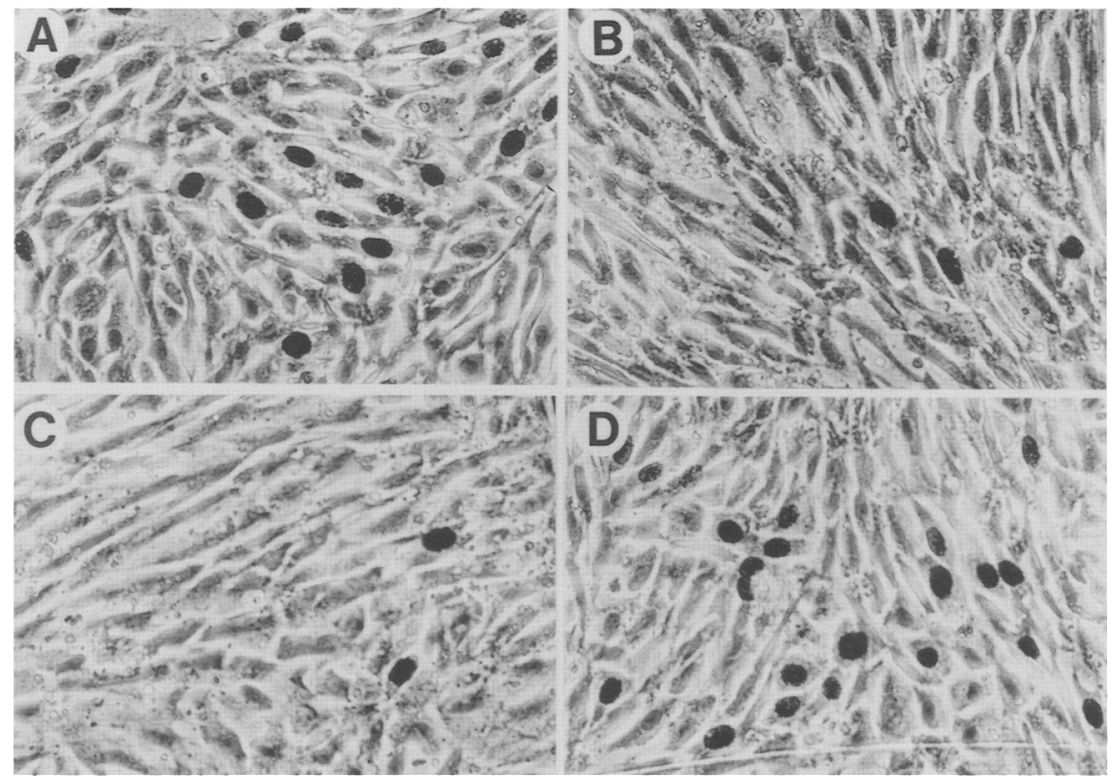


Table 3. The mitogenic signal of eIF-4E is blocked by neutralizing anti-Ras monoclonal antibody

\begin{tabular}{lc}
\hline Microinjected sample $^{\mathrm{a}}$ & $\begin{array}{c}\text { DNA synthesis } \\
\text { (fold induction) }\end{array}$ \\
\hline eIF-4E $\{3 \mathrm{mg} / \mathrm{ml})$ & $13.7(4.7)$ \\
eIF-4E $(\mathrm{Ala}-53)(2.5 \mathrm{mg} / \mathrm{ml})$ & $2.2(1.1)$ \\
$\mathrm{BSA}(2 \mathrm{mg} / \mathrm{ml}\}$ & $2.8(1.5)$ \\
eIF-4E $(3 \mathrm{mg} / \mathrm{ml})+\alpha 259(2 \mathrm{mg} / \mathrm{ml})$ & $1.7(0.8)$ \\
eIF-4E $(3 \mathrm{mg} / \mathrm{ml})+\alpha 238(2 \mathrm{mg} / \mathrm{ml})$ & $12.9(4.8)$ \\
\hline
\end{tabular}

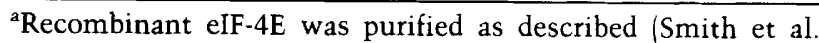
1990) (for details, see Materials and methods).

bata from at least three separate determinations. The values in parentheses are standard deviations of the mean (for details, see Materials and methods).

centration as wild-type Ras, failed to stimulate DNA synthesis (stimulation of less than twofold, as has been obtained by the injection of BSA; Table 4). In agreement with the original findings (Stacey and Kung 1984), the dominant-negative mutant of Ha-c-Ras blocked the mitogenic activity of wild type Ha-c-Ras in a dose-dependent manner, inhibiting $\sim 30 \%$ of activity at a concentration of $2 \mu \mathrm{g} / \mathrm{ml}$ but fully abrogating activity at 150 $\mu \mathrm{g} / \mathrm{ml}$. In a similar fashion, mutant Ha-c-Ras abrogated the induction of DNA synthesis by eIF- $4 \mathrm{E}$, when coinjected into serum-starved NIH-3T3 cells (Table 4; Fig. 8, cf. A and B). Microinjection of mutant Ha-c-Ras by itself had no effect on DNA synthesis (Fig. 8C).

\section{Discussion}

We present evidence for the involvement of Ras in eIF4E-mediated transformation by using three different approaches. First, we demonstrate that overexpression of eIF-4E results in Ras activation as evidenced by a threefold increase in the ratio of GTP/Ras to GDP/Ras in transformed relative to parental cells. This increase in Ras activity is not the result of an increase in the amount of Ras protein. Also, an increase in Ras protein is not expected to affect the equilibrium between GTP- and GDP-bound Ras (Barbacid 1987). Second, we demonstrate that GAP negatively regulates eIF-4E-transforming activity. Down-regulation of Ras by overexpression of GAP reverses the transforming phenotype caused by src (DeClue et al. 1991a; Nori et al. 1991) and CSF-1R (Bortner et al. 1991), placing these oncogenes upstream of Ras. We present similar evidence, through overexpression of GAP, that eIF-4E lies upstream of Ras. This conclusion is reinforced by experiments showing that expression of rap, or a dominant-negative mutant of ras, also results in reversion of the transformed phenotype (A. LazarisKaratzas and F. Lejbkowitz, unpubl.). Third, we show that anti-Ras antibodies or a dominant-negative Ras protein block the mitogenic activity of eIF-4E when coinjected with eIF-4E into serum-starved NIH-3T3 cells. Cumulatively, these data indicate that overexpressed eIF-4E is signaling through Ras and therefore lies upstream of Ras in a common signal transduction pathway.
How does eIF-4E increase the amount of Ras/GTP leading to activation of the Ras signaling cascade and transformation? One possible model is depicted in Figure 9. eIF-4E is believed to function in the unwinding of mRNA 5' secondary structure (Ray et al. 1985; Rozen et al. 1990). Consequently, this factor is predicted to enhance translation of inefficient mRNAs that contain extensive secondary structure in their $5^{\prime}$-noncoding region (Lazaris-Karatzas et al. 1990; Fagan et al. 1991). Because eIF-4E is limiting in the cell (Hiremath et al. 1985; Duncan et al. 1987), these mRNAs are expected to be discriminated against. Consistent with this hypothesis, recent results from our laboratory demonstrate that mRNAs containing extensive secondary structure in their 5'-untranslated region (UTR) could be translated efficiently in cells overexpressing eIF-4E (Koromilas et al., 1992). A high proportion of mRNAs with long 5'noncoding regions and extensive secondary structure encode proteins such as oncogene products, growth factors, and growth factor receptors, which play critical roles in cell growth, development, and differentiation. Thus, eIF$4 \mathrm{E}$ overexpression could engender a specific increase in the translation of mRNAs that control cell growth. Several growth factors and proto-oncogenes are translationally regulated. These include c-sis (Rao et al. 1988), lck (Marth et al. 1988), and FGF-5 (Bates et al. 1991). An increase in translation of a growth factor, such as FGF-5 or PDGF, which after secretion will bind to its receptor and activate signal transduction pathways, is consistent with our model. Several growth factors directly or through induction of a second messenger activate Ras into a GTP-bound, signal-generating state /Gibbs et al. 1990; Satoh et al. 1990). Thus, Ras is a major relay for several growth factor-mediated signaling pathways. Significantly, we have obtained preliminary evidence for an autocrine loop involving a growth factor in eIF-4E-over-

Table 4. Ha-c-Ras Asn-17, a dominant-negative mutant of $H a \cdot c-R a s$, inhibits the mitogenic signal of eIF-4E

\begin{tabular}{lc}
\hline Microinjected sample & $\begin{array}{r}\text { DNA synthesis } \\
\text { (fold induction) }\end{array}$ \\
\hline c-RAS $(250 \mu \mathrm{g} / \mathrm{ml})$ & $17.6(5.8)$ \\
BSA $(2 \mathrm{mg} / \mathrm{ml})$ & $1.9(1.2)$ \\
Ras Asn-17 $(200 \mu \mathrm{g} / \mathrm{ml})$ & $1.7(0.8)$ \\
Ras Asn-17 $(2 \mu \mathrm{g} / \mathrm{ml})+$ & $12.3(4.5)$ \\
c-Ras $(250 \mu \mathrm{ml})$ & \\
Ras Asn-17 $(150 \mu \mathrm{g} / \mathrm{ml})+$ & $2.6(1.9)$ \\
c-Ras $(250 \mu \mathrm{g} / \mathrm{ml})$ & $14.7(5.6)$ \\
eIF-4E $(3 \mathrm{mg} / \mathrm{ml})$ & $1.5(1.0)$ \\
eIF-4E $(3 \mathrm{mg} / \mathrm{ml})+$ & \\
Ras Asn-17 $(200 \mu \mathrm{g} / \mathrm{ml})$ & \\
\hline
\end{tabular}

E. coli-expressing Ha-c-Ras and Ras Asn-17 were obtained from L. Feig (Tufts University, Boston, MA), and protein was purified as described (Kung et al. 1986). Recombinant eIF-4E was purified as described (Smith et al. 1990) (for details, see Materials and methods|.

bata are from at least three separate determinations. The values in parentheses are standard deviations of the mean (for details, see Materials and methods|. 
Figure 8. The mitogenic activity of elF$4 \mathrm{E}$ is inhibited by coinjection of the mutant Ha-c-Ras Asn-17. Approximately 75 cells in the area of the photomicrograph were microinjected with eIF-4E $(3 \mathrm{mg} / \mathrm{ml})$ $(A)_{;}$eIF-4E $(3 \mathrm{mg} / \mathrm{ml})+\mathrm{Ha}-\mathrm{c}-$ Ras Asn- 17 $(150 \mu \mathrm{ml})(B)_{;}$and Ha-c-Ras Asn-17 $(200$ $\mu / \mathrm{ml})(C)$. After injection, the cultures were treated as described in the legend to Figure 7.

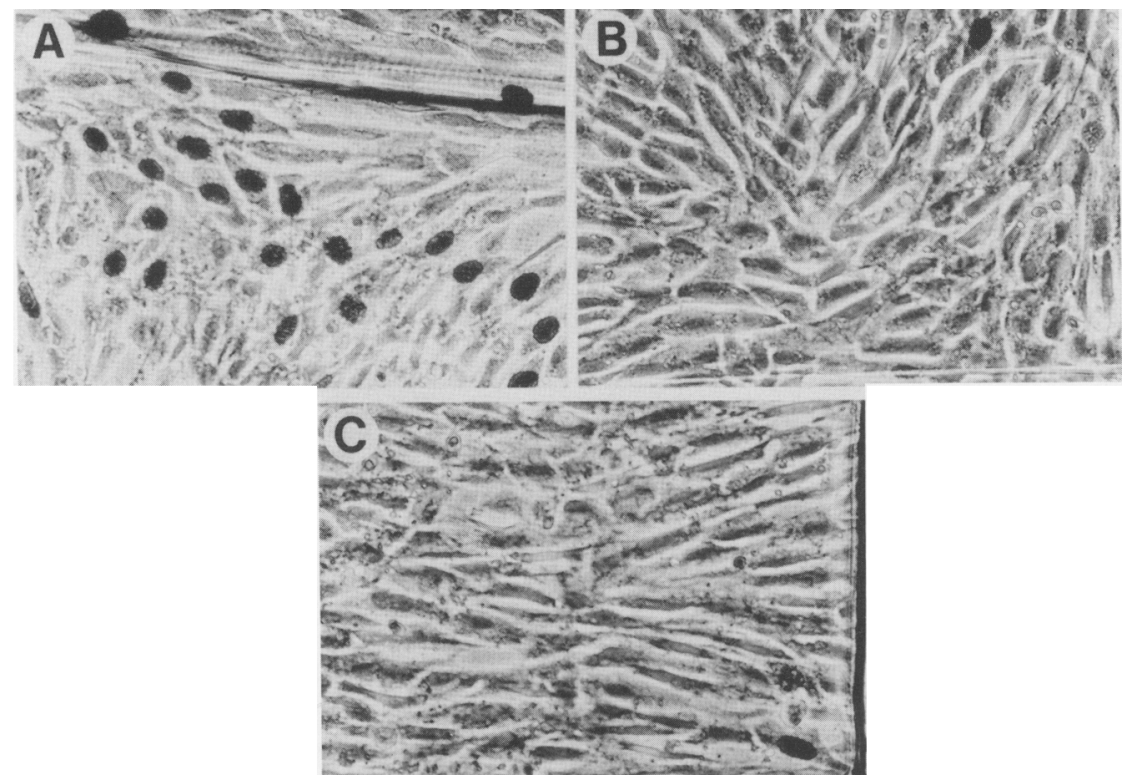

expressing cells, by showing that conditioned media from eIF-4E-transformed cells is capable of stimulating DNA synthesis in serum-starved NIH-3T3 cells (A. Lazaris-Karatzas, unpubl.). Whether growth factor expression results directly from eIF-4E overexpression or indi- rectly from Ras activation remains to be determined. Ras-transformed cells have been shown to produce and secrete their own growth factors (e.g., Peles et al. 1992). Additionally, growth factors can exert their activity without secretion, as demonstrated for v-sis, which ac-
Figure 9. Schematic model for transformation by eIF-4E (for details, see Discussion).

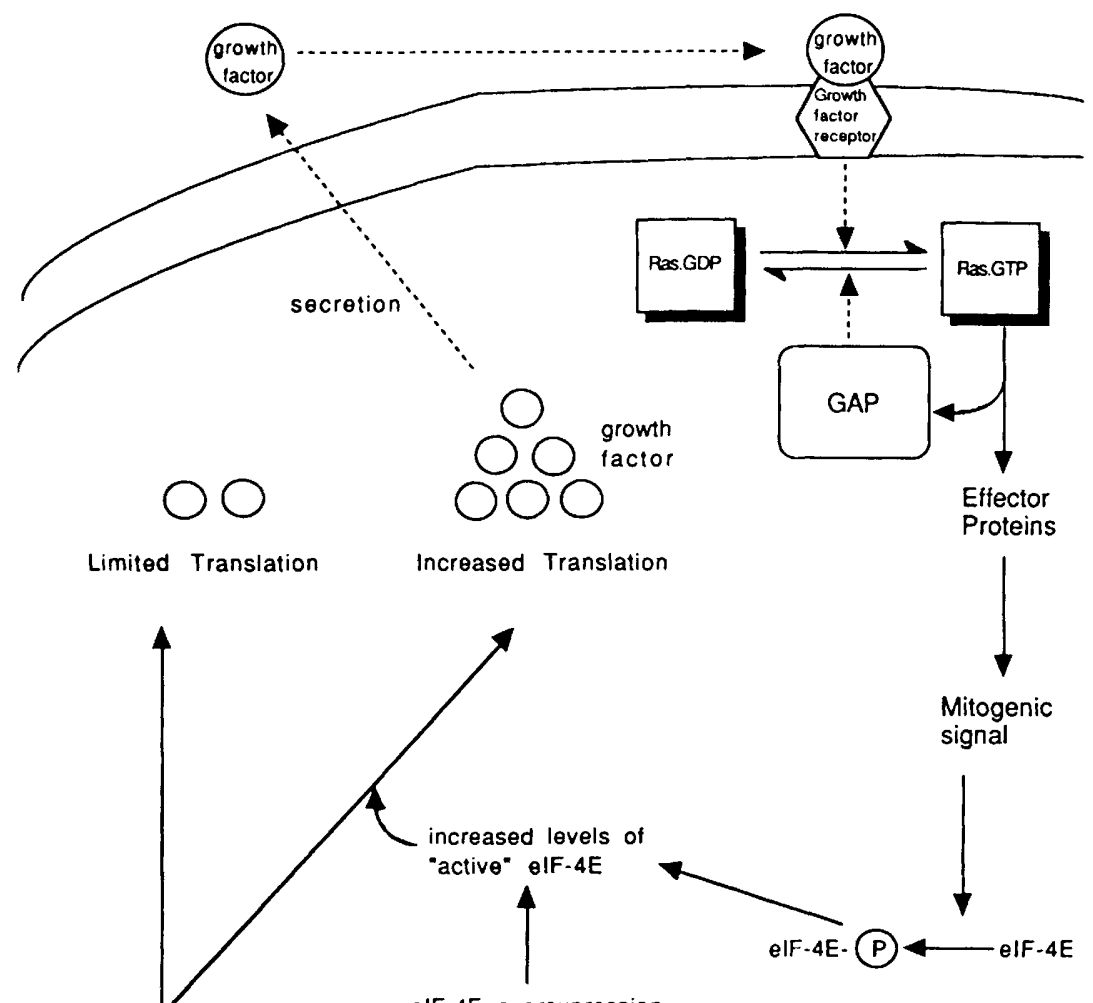

elF-4E overexpression

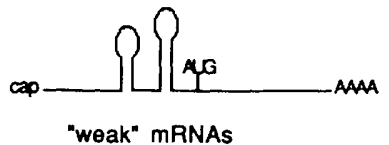


tivates Ras intracellularly (Bejcek et al. 1989). If our model is correct, it would seem to predict that microinjection of eIF-4E should activate DNA synthesis in surrounding uninjected cells, yet this is not observed in Figures 7 and 8. A likely explanation is that the amount of putative growth factor secreted from eIF-4E-microinjected cells is too small to exert a discernible effect on neighboring cells.

We have shown previously that eIF-4E phosphorylation in PC12 cells is mediated through Ras. Inactivation of Ras in PC12 cells, by expression of a dominant-negative mutant (Ha-c-Ras-Asn-17), prevents the NGF-mediated increase in eIF-4E phosphorylation. This result suggests that eIF-4E activity in these cells depends on and lies downstream of Ras (Frederickson et al. 1992). Also, factors that stimulate protein synthesis such as mitogens and expression of tyrosine kinases, some of which have been demonstrated to activate Ras, increase eIF-4E phosphorylation (for a recent review, see Frederickson and Sonenberg 1992). Furthermore, eIF-4E phosphorylation is increased in CREF cells transformed with activated Ras and in v-ras-transformed Rat 1 cells (RinkerSchaeffer et al. 1992; R.M. Frederickson, unpubl.). A possible activity of Ras in elF-4E-overexpressing cells would therefore be to act in a possible feedback loop to enhance eIF-4E activity, by increasing its phosphorylation levels. The results presented in this paper, however, demonstrate that down-regulation of Ras activity does not affect eIF-4E phosphorylation, suggesting that overexpression of GAP does not down-regulate Ras sufficiently to cause a decrease in eIF-4E phosphorylation. Revertant cell lines maintain high levels of eIF-4E phosphorylation with reduced levels of active Ras. We suggest, therefore, that the comparatively low levels of active Ras in GAPoverexpressing cells are sufficient to maintain eIF-4E phosphorylation, whereas higher levels of active Ras are required to transform cells.

In summary, we have established an important link between Ras, which plays a key role in cellular signal transduction, and eIF-4E, which is a critical component of the translation machinery. The data presented here strongly support the idea that Ras and eIF-4E function along the same signaling pathway and that the transforming and mitogenic activities of eIF- $4 \mathrm{E}$ are mediated through the activation of Ras. Thus, the interaction between the Ras signaling system and eIF-4E should control cell proliferation. Inasmuch as translation activation is a key event in the repertoire of cellular responses to extracellular growth stimuli, further studies on the interdigitation between the Ras signaling pathway and protein synthesis should yield a better understanding of the regulation of cell growth.

\section{Materials and methods}

\section{Cell culture}

NIH-3T3 and E1A-immortalized REFs were cultured in Dulbecco's modified Eagle medium (DMEM) supplemented with $10 \%$ fetal calf serum (FCS, GIBCO Laboratories, Grand Island, NY). Transformed NIH-3T3/eIF-4E cell line /clone P2, generated as described by Lazaris-Karatzas et al. 1990) and parental REF/ E1A/pMV7/eIF-4E and REF/pMV7/eIF-4E cell lines /generated as described by Lazaris-Karatzas and Sonenberg 1992/ were cultured in DMEM supplemented with $10 \%$ FCS and $500 \mu \mathrm{g} / \mathrm{ml}$ of G418 (Geneticin, GIBCO Laboratories). Revertant cell lines, $\mathrm{REF} / \mathrm{pMV}$ /eIF-4E + hGAP, and their control cell line REF/ pMV7/eIF-4E were maintained in DMEM plus $10 \%$ FCS, 500 $\mu \mathrm{g} / \mathrm{ml}$ of $\mathrm{G} 418$, and $50 \mu \mathrm{g} / \mathrm{ml}$ of hygromycin B (Sigma).

\section{Overexpression of hGAP and isolation of revertants}

The human GAP gene was overexpressed by use of CMV-based expression vector CDM-8 (Aruffo and Seed 1987) as follows: pUC101a, a generous gift from F. McCormick (Chiron Corporation, CA), was restricted with EcoRI, releasing a 4-kb cDNA fragment encoding the full-length human GAP protein. The fragment was blunt-ended with Klenow and subcloned into the expression vector CDM- 8 . The hGAP expression vector or control expression vector lacking hGAP was cotransfected at a $10: 1$ ratio with the plasmid pSV2Hyg, which expresses the hygromycin resistance gene under the control of the SV40 promoter. Transfections into elF-4E-transformed REFs were performed by use of the calcium phosphate-mediated method (Wigler et al. 1972). Briefly, eIF-4E-transformed REFs were plated at $5 \times 10^{5}$ cells $/ 100-\mathrm{mm}$ dish $24 \mathrm{hr}$ before transfection. Cells were cotransfected with $5 \mu \mathrm{g}$ of recombinant CDM-8, 0.5 $\mu \mathrm{g}$ of pSV2 Hyg, and carrier DNA to a final concentration of 15 $\mu \mathrm{g}$. The precipitate was applied to the cells for $24 \mathrm{hr}$ before selection with hygromycin B $(50 \mu \mathrm{g} / \mathrm{ml})$. Plates were refed every 2-3 days with DMEM supplemented with $10 \%$ FCS, G418, and hygromycin $\mathrm{B}$. Individual colonies were isolated by use of the cloning cylinder method and expanded after 3-4 weeks.

\section{Growth in soft agar and tumorigenicity assay}

Analyses of soft agar growth and tumorigenesis in nude mice were performed as described previously (Lazaris-Karatzas et al. 1990). Briefly, for analysis in soft agar, $2 \times 10^{4}$ cells were seeded in duplicate in $30-\mathrm{mm}$ dishes with $4 \mathrm{ml}$ of DMEM containing $20 \%$ FCS with the appropriate selection and $0.33 \%$ agar solution at $37^{\circ} \mathrm{C}$. Cells were fed with $2 \mathrm{ml}$ of DMEM plus G418 every 7 days. Growth was scored as colonies containing $>10$ cells, 21 days after plating.

To test for tumorigenicity, $\mathrm{CDl} \mathrm{nu} / \mathrm{nu}$ mice were injected subcutaneously with $10^{6}$ cells, resuspended in $100 \mu \mathrm{l}$ of PBS. Mice that developed tumors were killed after 21 days. Mice that did not develop tumors were observed for 90 days.

\section{Northern blot analysis}

Northern blot analysis was performed as described previously (Lazaris-Karatzas et al. 1990). Briefly, $2 \mu \mathrm{g}$ of poly(A) ${ }^{+}$mRNA was electrophoresed, blotted, and hybridized to a ${ }^{32} \mathrm{P}$-labeled, random-primed probe, containing the entire coding region of elF-4E. Filters were washed at a final stringency of $0.5 \times$ SSC and $0.1 \% \mathrm{SDS}$ for $60 \mathrm{~min}$ at $65^{\circ} \mathrm{C}$.

\section{Metabolic labeling of cells and immunoprecipitation}

For steady-state metabolic labeling with $\left[{ }^{35} \mathrm{~S}\right]$ methionine, $\sim 5 \times 10^{5}$ cells were seeded in $60-\mathrm{mm}$ culture dishes $24 \mathrm{hr}$ before labeling. Cells were washed twice with methionine-free DMEM and labeled for $18 \mathrm{hr}$ with $2 \mathrm{ml}$ of methionine-free DMEM containing $0.45 \mu \mathrm{Ci} / \mathrm{ml}$ of [35S]methionine (New England Nuclear, $597.5 \mathrm{Ci} / \mathrm{mmole}$ ) and supplemented with $10 \%$ dialyzed FCS in $10 \mathrm{~mm}$ HEPES KOH (ph 7.0). To prepare ex- 
tracts, cells were washed twice with ice-cold PBS, lysed with 1 $\mathrm{ml}$ of RIPA buffer [150 mM NaCl, $1 \% \mathrm{NP}-40,0.5 \%$ sodium deoxycholate, $0.1 \%$ SDS, $50 \mathrm{~mm}$ Tris- $\mathrm{HCl}(\mathrm{pH} 8.0), 20 \mu \mathrm{M}$ sodium vanadate, $0.2 \mathrm{~mm}$ PMSF, $50 \mathrm{~mm} \mathrm{NaF}, 10 \mathrm{~mm} \mathrm{NaPPi}, 1 \mathrm{~mm}$ EGTA], and clarified by centrifugation for $15 \mathrm{~min}$ at $10,000 \mathrm{~g}$. The supernatant was removed and frozen at $-70^{\circ} \mathrm{C}$.

For metabolic labeling, cells were serum-starved overnight in phosphate-free DMEM and labeled for $3 \mathrm{hr}$ with $0.5 \mathrm{mCi}$ [ ${ }^{32} \mathrm{P}$ ]orthophosphate (New England Nuclear, $8500 \mathrm{Ci} / \mathrm{mmole}$ )/ $35-\mathrm{mm}$ dish in the same media.

Immunoprecipitation of $\left[{ }^{32} \mathrm{~S}\right]$ methionine-labeled extracts was performed with lysates containing equal amounts of trichloroacetic acid (TCA)-precipitable counts per minute. Equal numbers of counts per minute of ${ }^{32} \mathrm{P}$-labeled extracts were immunoprecipitated. The lysates were incubated overnight with a polyclonal rabbit antibody against a mouse eIF-4E synthetic peptide at $4^{\circ} \mathrm{C}$ with rotation and then with $60 \mu \mathrm{l}$ of $10 \%$ suspension of protein A-Sepharose, prewashed in lysis buffer, for an additional hour. Immunocomplexes were washed twice with $1 \mathrm{ml}$ of lysis buffer, twice with $1 \mathrm{ml}$ of lysis buffer with the addition of $250 \mu \mathrm{l}$ of $5 \mathrm{M} \mathrm{NaCl}$, twice with $1 \mathrm{ml}$ of PBS, boiled for $5 \mathrm{~min}$ in sample buffer, and loaded onto a $12.5 \%$ SDS-polyacrylamide gel. After electrophoresis, the $\left[{ }^{35} \mathrm{~S} \mid \mathrm{methionine-la-}\right.$ beled gels were fixed, enhanced, rinsed with water, dried, and exposed to film at $-70^{\circ} \mathrm{C}$. The $\left[{ }^{32} \mathrm{P} \mid\right.$ orthophosphate-labeled gels were dried and exposed to film at $-70^{\circ} \mathrm{C}$ with two intensifying screens.

\section{Western blot analysis}

A confluent $100-\mathrm{mm}$ dish was washed twice with PBS, lysed in TNE buffer [50 mM Tris- $\mathrm{HCl}(\mathrm{pH} 8.0), 1 \%$ NP-40, 2 mM EDTA, $50 \mathrm{~mm} \mathrm{NaF}, 0.2 \mathrm{mM}$ PMSF, $1 \mathrm{mg} / \mathrm{ml}$ of aprotinin, $1 \mathrm{mg} / \mathrm{ml}$ of leupeptin, $20 \mu \mathrm{M}$ sodium vanadatel, and clarified at $10,000 \mathrm{~g}$. Protein content of the lysate was determined by use of the Bradford assay (Bio-Rad) and $75 \mu \mathrm{g}$ of each lysate was analyzed on a $15 \%$ SDS-polyacrylamide gel. Proteins were electroblotted onto a nylon membrane (Schleicher \& Schuell), blocked for $1 \mathrm{hr}$ in $5 \%$ dry skim milk powder at room temperature, incubated with a rabbit anti-human GAP antibody (a generous gift from $T$. Pawson, Mount Sinai Hosp. Research Center, Toronto, Canada) at a dilution of $1: 200$ for $90 \mathrm{~min}$, washed, and incubated with $0.1 \mu \mathrm{Ci} / \mathrm{ml}$ of ${ }^{125} \mathrm{I}$-conjugated protein $\mathrm{A}$ (New England Nuclear) for $1 \mathrm{hr}$. The membrane was then washed, dried, and autoradiographed at $-70^{\circ} \mathrm{C}$.

Western blot analysis of $\mathrm{p} 21 /$ Ras was performed by immunoprecipitation of Ras, as described below, from $100 \mu \mathrm{g}$ of total cell lysates, followed by electrophoresis of the immunoprecipitate on a $12.5 \%$ SDS-polyacrylamide gel. Proteins were electroblotted onto nylon membranes (Immobilon P, Amersham), blocked, as described above, incubated with anti-p21/Ras monoclonal antibody for $2 \mathrm{hr}$, washed, and incubated with sheep anti-mouse IgG-coupled horseradish peroxidase for 30 min. The membrane was then washed, developed with ECL detection kit (Amersham, Canada), and exposed to film for 20 sec.

\section{Detection of guanine nucleotides bound to Ras}

Assays were performed as described by DeClue et al. (1991b), except for some modifications. Approximately $2 \times 10^{6}$ cells were seeded in $60-\mathrm{mm}$ dishes; $24 \mathrm{hr}$ later, the cells were washed with phosphate-free, serum-free DMEM, serum starved for 7-8 $\mathrm{hr}$, and labeled for $10 \mathrm{hr}$ with $0.5 \mathrm{mCi} / \mathrm{ml}$ of $\left[{ }^{32} \mathrm{P}\right]$ orthophosphate. Cells were washed with ice-cold PBS and lysed on ice for $10 \mathrm{~min}$ with $600 \mu \mathrm{l}$ of ice-cold lysis buffer $[20 \mathrm{mM}$ Tris- $\mathrm{HCl} / \mathrm{pH}$ 7.5), $5 \mathrm{mM} \mathrm{MgCl}_{2}, 150 \mathrm{mM} \mathrm{NaCl}, 0.5 \% \mathrm{NP}-40,1 \mathrm{mg} / \mathrm{ml}$ of leu- peptin, and $0.2 \mathrm{mM} \mathrm{PMSF].} \mathrm{Cell} \mathrm{debris} \mathrm{was} \mathrm{spun} \mathrm{down} \mathrm{at}$ $10,000 \mathrm{~g}$, and the supernatant was incubated with $3 \mu \mathrm{l}$ of antip21/Ras monoclonal Y13-259 antibody $(0.1 \mathrm{mg} / \mathrm{ml})$ for $1 \mathrm{hr}$ at $4^{\circ} \mathrm{C}$ with rotation. Sixty microliters of rabbit anti-rat IgG /Cappel Laboratories/ coupled to protein A-Sepharose was added and incubated for an additional hour. Immunocomplexes were washed eight times with $1 \mathrm{ml}$ of ice-cold washing buffer $[50 \mathrm{mM}$ Tris- $\mathrm{HCl}(\mathrm{pH} 7.5), 20 \mathrm{~mm} \mathrm{MgCl}_{2}, 0.1 \%$ Triton X-100, $0.005 \%$ SDS, and $100 \mathrm{~mm} \mathrm{NaCl}$ and once with $10 \mathrm{~mm}$ Tris- $\mathrm{HCl}(\mathrm{pH} 7.5)$ and $20 \mathrm{mM} \mathrm{MgCl}_{2}$. GTP/GDP was eluted in $20 \mathrm{mM}$ Tris- $\mathrm{HCl}$ (pH 7.5), $0.2 \%$ SDS, $0.5 \mathrm{~mm} \mathrm{GDP}$, and $0.5 \mathrm{mM} \mathrm{GTP}$ at $68^{\circ} \mathrm{C}$ for $20 \mathrm{~min}$, separated on polyethyleneimine (PEI)-cellulose thin layer plates (Brinkmann Instruments, Canada), and developed in $0.75 \mathrm{M}$ potassium phosphate $\left[\mathrm{KH}_{2} \mathrm{PO}_{4}(\mathrm{pH} 3.4)\right]$. Plates were dried and exposed to film at $-70^{\circ} \mathrm{C}$ with an intensifying screen. Autoradiographs were quantified with Biolmager (MilliGen/Biosearch, Millipore, Canada). Results are expressed as the percentage of the amount of GTP relative to total GTP + GDP and corrected for moles of phosphate per mole of guanosine, assuming uniform labeling of all phosphates.

\section{Microiniections}

NIH-3T3 cells $\left(3 \times 10^{4}\right)$ were seeded on glass coverslips in 35 $\dot{\mathrm{mm}}$ dishes and allowed to grow to confluence. The medium was removed and medium containing $0.5 \%$ FCS was applied for 24 hr. Coded samples were mixed together and injected into quiescent cells at the concentrations indicated. The coverslips were maintained in low-serum media for $20 \mathrm{hr}$ and then pulsed with $\left[{ }^{3} \mathrm{H}\right]$ thymidine $[0.5 \mu \mathrm{Ci} / \mathrm{ml})$ for $4 \mathrm{hr}$. Cells were washed with PBS, fixed in $3.5 \%$ gluteraldehyde/PBS, coated with photographic emulsion (NTB2), and exposed to X-ray film for $48 \mathrm{hr}$. eIF-4E and monoclonal antibodies against $\operatorname{Ras} \mid \alpha 259$ and $\alpha 238\}$ were purified as described (Smith et al. 1990; Kung et al. 1986, respectivelyl.

Fold induction of DNA synthesis was calculated by determining the percentage of injected cells that incorporated $\left[{ }^{3} \mathrm{H}\right]$ thymidine and dividing by the percentage of uninjected cells in the vicinity of the incorporated label. Standard deviation from at least four separate experiments is shown in Tables 3 and 4.

\section{Acknowledgments}

We thank A. Veillette for valuable advice during the course of this work and S. Roy, S. Mader, M. Szyf, and A. Veillette for critical comments on the manuscript. We thank T. Wood for technical assistance and T. Pawson, F. McCormick, L. Feig, and J. Gibbs for reagents. This research was supported by grants from the National Cancer Institute of Canada, with funds from the Canadian Cancer Society to N.S., and by funds from the Department of Health and Human Services under contract number N01-CO-74102 with Program Resources, Inc./DynCorp. A.L.-K. is the recipient of a predoctoral studentship from the Cancer Research Society. R.F. is the recipient of a predoctoral studentship from the Medical Research Council of Can ada, and M.J. was the recipient of a predoctoral studentship from Fonds de la Recherche en Santé du Québec Fellowship.

The publication costs of this article were defrayed in part by payment of page charges. This article must therefore be hereby marked "advertisement" in accordance with 18 USC section 1734 solely to indicate this fact.

\section{References}

Aruffo, A. and B. Seed. 1987. Molecular cloning of a CD28 cDNA by a high efficiency COS cell expression system. Proc Natl. Acad. Sci. 84: 8573-8577. 
Barbacid, M. 1987. Ras genes. Annu. Rev. Biochem. 56: 779827.

Bates, B., J. Hardin, X. Zhan, K. Drickamer, and M. Goldfarb. 1991. Biosynthesis of human fibroblast growth factor-5. Mol. Cell. Biol. 11: 1840-1845.

Bejcek, B.E., D.Y. Li, and T.F. Deuel. 1989. Transformation by $\mathrm{v}$-sis occurs by an internal autoactivation mechanism. Science 245: 1496-1499.

Bonneau, A.M. and N. Sonenberg. 1987. Involvement of the $24 \mathrm{kDa}$ cap binding protein in regulation of protein synthesis in mitosis. I. Biol. Chem. 262: 11134-11139.

Bortner, D.M., M. Ulivi, M.F. Roussel, and M.C. Ostrowski. 1991. The carboxy terminal catalytic domain of the GTPase activating protein inhibits nuclear signal transduction and morphological transformation mediated by the CSF-1 receptor. Genes «Dev. 6: 1777-1785.

Bourne, H.R., D.A. Sanders, and F. McCormick. 1990. The GTPase superfamily: A conserved switch for diverse cell function. Nature 348: 125-132.

deBenedetti, A. and R.E. Rhoads. 1990. Overexpression of eukaryotic protein synthesis initiation factor $4 \mathrm{E}$ in HeLa cells results in aberrant growth and morphology. Proc. Natl. Acad. Sci. 87: 8212-8216.

DeClue, J.E., K. Zhang, P. Redford, W.C. Vass, and D.R. Lowy. 1991a. Suppression of src transformation by overexpression of full-length GTPase-activating protein (GAP) or of the GAP C terminus. Mol. Cell. Biol. 11: 2819-2825.

DeClue, J.E., J.C. Stone, R.A. Blanchard, A.G. Papageorge, P. Martin, K. Zhang, and D.R. Lowy. 1991b. A ras effector domain mutant which is temperature sensitive for cellular transformation: Interactions with GTPase-activating protein and NF-1. Mol. Cell. Biol. 11: 3132-3138.

Duncan, R., S.C. Milburn, and J.W.B. Hershey. 1987. Regulated phosphorylation and low abundance of HeLa cell initiation factor eIF-4F suggest a role in translation control. I. Biol. Chem. 262: 380-388.

Ellis, C., M. Moran, F. McCormick, and T. Pawson. 1990. Phosphorylation of GAP and GAP-associated proteins by transforming and mitogenic tyrosine kinases. Nature 343: 377381.

Fagan, R., A. Lazaris-Karatzas, N. Sonenberg, and R. Rozen. 1991. Translational control of ornithine aminotransferase: Modulation by initiation factor eIF-4E. I. Biol. Chem. 266: 16518-16521.

Feig, L.A. and G.M. Cooper. 1988. Inhibition of NIH 3T3 cell proliferation by a mutant ras protein with preferential affinity for GDP. Mol. Cell. Biol. 8: 3235-3243.

Frederickson, R.M. and N. Sonenberg. 1992. Signal transduction and the regulation of translation. Sem. Cell Biol. 3: 105-113.

Frederickson, R.M., K. Montine, and N. Sonenberg. 1991. Phosphorylation of eukaryotic translation initiation factor $4 \mathrm{E}$ is increased in src-transformed cell lines. Mol. Cell. Biol. 11: 2896-2900.

Frederickson, R.M., W.E. Mushynski, and N. Sonenberg. 1992. Phosphorylation of translation initiation factor eIF-4E is induced in a ras-dependent manner during nerve growth factor mediated PC12 cell differentiation. Mol. Cell. Biol. 12: 1239-1247.

Furth, M.E., L.J. Davis, B. Fleurdelys, and E.M. Scolnick. 1982. Monoclonal antibodies to the $\mathrm{p} 21$ products of the transforming gene of Harvey murine sarcoma virus and of the cellular ras gene family. J. Virol. 43: 294-304.

Gibbs, J.B., M.D. Schaber, V.M. Garsky, U.S. Vogel, E.M. Scolnick, R.A.F. Dixon, and M.S. Marshall. 1990. Structure function relationships of Ras and guanosine triphosphatase-activating protein. In G-proteins and signal transduction. fed.
N.M. Nathanson and T.K. Harden|, pp. 77-85. Rockefeller University Press, New York.

Hershey, J.W.B. 1991. Translational control in mammalian cells. Annu. Rev. Biochem. 60: 717-755.

Hiremath, L.S., N.R. Webb, and R.E. Rhoads. 1985. Immunological detection of the messenger RNA cap-binding protein. I. Biol. Chem. 260: 7843-7849.

Huang, J. and R.J. Schneider. 1991. Adenovirus inhibition of cellular protein synthesis involves inactivation of cap binding protein. Cell 65: 271-280.

Jaramillo, M., T.E. Dever, W.C. Merrick, and N. Sonenberg 1991. RNA unwinding in translation: Assembly of helicase complex intermediates comprising eukaryotic initiation factors eIF-4F and eIF-4B. Mol. Cell. Biol. 11: 5992-5997.

Joshi-Barve, S., W. Rychlik, and R.E. Rhoads. 1990. Alteration of the major phosphorylation site of eukaryotic protein synthesis initiation factor $4 \mathrm{E}$ prevents its association with the $48 \mathrm{~S}$ initiation complex. J. Biol. Chem. 265: 2979-2983.

Kaspar, R.L., W. Rychlik, M.W. White, R.E. Rhoads, and D.R. Morris. 1990. Simultaneous cytoplasmic redistribution of ribosomal protein L32 mRNA and phosphorylation of eukaryotic initiation factor $4 \mathrm{E}$ after mitogenic stimulation of Swiss 3T3 cells. J. Biol. Chem. 265: 3619-3622.

Koromilas, A.E., A. Lazaris-Karatzas, and N. Sonenberg. 1992. mRNAs containing extensive secondary structure in their $5^{\prime}$ non-coding region translate efficiently in cells overexpressing initiation factor eIF-4E. EMBO $J$. (in press).

Kozak, M. 1986. Point mutations define a sequence flanking the AUG initiator codon that modulates translation by eukaryotic ribosomes. Cell 44: 283-292.

Kung, H.-F., M.R. Smith, E. Bekesi, V. Manne, and D.W. Stacey. 1986. Reversal of transformed phenotype by monoclonal antibodies against Ha-ras p2l protein. Exp. Cell. Res. 162: 363371.

Lazaris-Karatzas, A. and N. Sonenberg. 1992. The mRNA 5' cap-binding protein, eIF-4E, cooperates with v-myc or E1A in the transformation of primary rodent fibroblasts. Mol. Cell. Biol. 12: 1234-1238.

Lazaris-Karatzas, A., K.S. Montine, and N. Sonenberg. 1990. Malignant transformation by a eukaryotic initiation factor subunit that binds to mRNA 5 ' cap. Nature 345: 544-547.

Manzella, J.M. and P.I. Blackshear. 1990. Regulation of rat ornithine decarboxylase mRNA translation by its $5^{\prime}$-untranslated region. I. Biol. Chem. 265: 11817-11822.

Marino, M.W., L.M. Pfeffer, P.T. Guidon, and D.B. Donner. 1989. Tumor necrosis factor induces phosphorylation of a $28 \mathrm{kDa}$ mRNA cap-binding protein in human cervical carcinoma cells. Proc. Natl. Acad. Sci. 86: 8417-8421.

Marth, J.D., R.W. Overell, K.E. Meier, E.G. Krebs, and R.M. Perlmutter. 1988. Translational activation of the $1 \mathrm{ck}$ protooncogene. Nature 332: 171-173.

Morley, S.J. and J.A. Traugh. 1989. Phorbol esters stimulate phosphorylation of eukaryotic initiation factors $3,4 \mathrm{~B}$ and $4 \mathrm{~F}$. I. Biol. Chem. 264: 2401-2404.

- 1990. Differential stimulation of phosphorylation of initiation factors eIF-4F, eIF-4B, eIF-3 and ribosomal protein S6 by insulin and phorbol esters. I. Biol. Chem. 265: 1061110616.

Morley, S.J., T.E. Dever, D. Etchison, and J.A. Traugh. 1991. Phosphorylation of eIF-4F by protein kinase $\mathrm{C}$ or multipotential $\mathrm{S} 6$ kinase stimulates protein synthesis at initiation. $J$. Biol. Chem. 266: 4669-4672.

Mulcahy, L.S., M.R. Smith, and D.W. Stacey. 1985. Requirement for ras proto-oncogene function during serum-stimulated growth of NIH 3T3 cells. Nature 313: 241-243.

Nielsen, P.J. and H. Trachsel. 1988. The mouse protein synthe- 
sis initiation factor $4 \mathrm{~A}$ gene family includes two related functional genes which are differentially expressed. $E M B O J$. 7: 2097-2105.

Nori, M., U.S. Vogel, J.B. Gibbs, and M.J. Weber. 1991. Inhibition of v-src induced transformation by a GTPase-activating protein. Mol. Cell. Biol. 11: 2812-2818.

Pause, A. and N. Sonenberg. 1992. Mutational analysis of a DEAD RNA helicase; The translation initiation factor eIF4A. EMBO I. 11: 2643-2654.

Peles, E., S.S. Bacus, R.A. Koski, H.S. Lu, D. Wen, S.G. Ogden, R.B. Levy, and Y. Yarden. 1992. Isolation of the Neu/HER-2 stimulatory ligand: A $44 \mathrm{kd}$ glycoprotein that induces differentiation of mammary tumor cells. Cell 69: 205-216.

Pelletier, J. and N. Sonenberg. 1985. Insertion mutagenesis to increase secondary structure within the 5 ' non-coding region of a eukaryotic mRNA reduces translational efficiency. Cell 40: $515-526$.

Rao, C.D., M. Pech, K.C. Robbins, and S.A. Aaronson. 1988. The 5 ' untranslated sequence of the c-sis/platelet-derived growth factor 2 transcript is a potent translational inhibitor. Mol. Cell. Biol. 8: 284-292.

Ray, B.K., T.G. Lawson, J.C. Kramer, M.H. Cladaras, J.A. Grifo, R.B. Abramson, W.C. Merrick, and R.E. Thach. 1985. ATPdependent unwinding of messenger RNA structure by eukaryotic initiation factors. I. Biol. Chem. 260: 7651-7658.

Rhoads, R.E. 1988. Cap recognition and entry of mRNA into the protein synthesis initiation cycle. Trends Biochem. Sci. 13: $52-56$

Rinker-Schaeffer, C.W., V. Austin, S. Zimmer, and R.E. Rhoads. 1992. ras transformation of cloned rat embryo fibroblasts results in increased rates of protein synthesis and phosphorylation of eukaryotic initiation factor 4E. $\%$. Biol. Chem. 267: 2593-2598.

Rozen, F., I. Edery, K. Meerovitch, T.E. Dever, W.C. Merrick, and N. Sonenberg. 1990. Bidirectional RNA helicase activity of eukaryotic translation initiation factor $4 \mathrm{~A}$ and $4 \mathrm{~F}$. Mol. Cell. Biol. 10: 1134-1144.

Rychlik, W., M.A. Russ, and R.E. Rhoads. 1987. Phosphorylation site of eukaryotic initiation factor 4E. J. Biol. Chem. 262: 10434-10437.

Satoh, T., M. Endo, M. Nakafuku, S. Nakamura, and Y. Kaziro. 1990. Platelet-derived growth factor stimulates formation of active p21 ras - GTP complex in Swiss mouse 3T3 cells. Proc. Natl. Acad. Sci. 87: 5993-5997.

Smith, M.R., S.J. DeGudicibus, and D.W. Stacey. 1986. Requirement for c-ras proteins during viral oncogene transformation. Nature 320: 540-543.

Smith, M.R., M. Jaramillo, Y.-L. Liu, T.E. Dever, W.C. Merrick, H.-F. Kung, and N. Sonenberg. 1990. Translation initiation factors induce DNA synthesis and transform NIH 3T3 cells. New Biol. 2: 648-654.

Sonenberg, N. 1987. Regulation of translation by poliovirus. Adv. Virus Res. 3: 175-204.

1988. Cap binding protein of eukaryotic messenger RNA: Function in initiation and control of translation. Prog. Nucleic Acid Res. Mol. Biol. 35: 174-207.

Stacey, D.W. and H.-F. Kung. 1984. Transformation of NIH 3T3 cells by microinjection of $\mathrm{Ha}$-ras $\mathrm{p} 2 \mathrm{l}$ protein. Nature 310: 508-511.

Stacey, D.W., S.J. DeGudicibus, and M.R. Smith. 1987. Cellular ras activity and tumor cell proliferation. Exp. Cell. Res. 171: 232-242.

Trahey, M. and F. McCormick. 1987. A cytoplasmic protein stimulates normal N-ras p21 GTPase, but does not affect oncogenic mutants. Science 238: 542-545.

Veillette, A., L. Caron, M. Fournel, and T. Pawson. 1992. Reg- ulation of the enzymatic function of the lymphocyte-specific tyrosine protein kinase p56 ${ }^{\text {lck }}$ by the non-catalytic $\mathrm{SH} 2$ and SH3 domains. Oncogene 7: 971-980.

Wigler, M., A. Pellicer, S. Silverstein, R. Axel, G. Urlaub, and L. Chasin. 1972. DNA-mediated transfer of the adenine phosphoribosyltransferase locus into mammalian cells. Proc. Natl. Acad. Sci. 76: 1373-1376. 


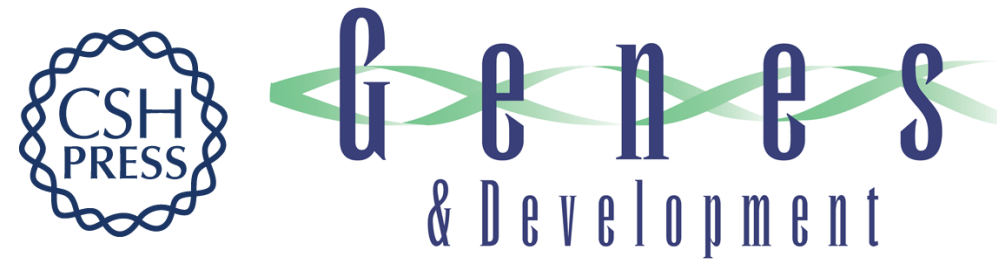

\section{Ras mediates translation initiation factor $4 \mathrm{E}$-induced malignant transformation.}

A Lazaris-Karatzas, M R Smith, R M Frederickson, et al.

Genes Dev. 1992, 6:

Access the most recent version at doi:10.1101/gad.6.9.1631

References This article cites 56 articles, 30 of which can be accessed free at: http://genesdev.cshlp.org/content/6/9/1631.full.html\#ref-list-1

License

Email Alerting

Service

Receive free email alerts when new articles cite this article - sign up in the box at the top right corner of the article or click here.

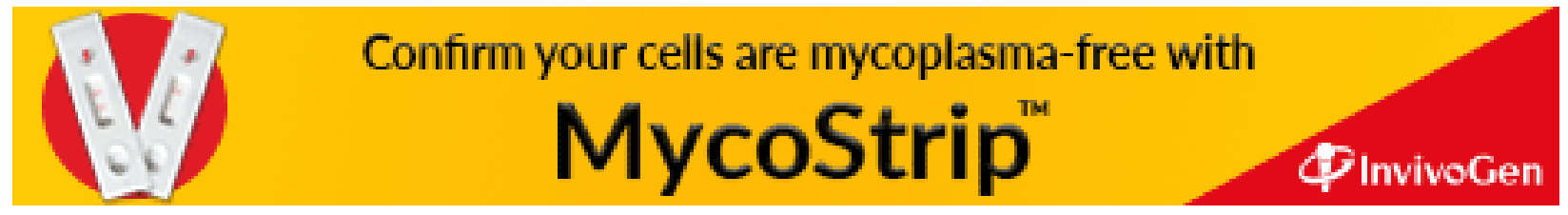

